\title{
Crop Water Requirements in Cameroon's Savanna Zones Under Climate Change Scenarios and Adaptation Needs
}

\author{
Genesis T. Yengoh ${ }^{1}$, Sara Brogaard ${ }^{2}$ and Lennart Olsson ${ }^{2}$ \\ ${ }^{1}$ Department of Earth and Ecosystem Sciences Division of Physical Geography and \\ Ecosystem Analysis Lund University Sölvegatan 12, SE-223 62 Lund, \\ ${ }^{2}$ Lund University Centre for Sustainability Studies Geocentrum 1, Sölvegatan 10, Lund
}

Sweden

\section{Introduction}

Rain-fed agriculture is practiced on approximately 80 percent of global agricultural land area (Wani et al. 2009). It accounts for about 70 percent of the global staple foods production (Cooper et al. 2009). This is the main mode of production favored by poor farmers in the developing world and other economically deprived societies (Wani et al. 2009). The contribution to global food supply from rain-fed agriculture is forecasted to decline from 65 percent at present to 48 percent in 2030 (Bruinsma 2003). The decline of precipitation forecast for some regions of the African savanna may affect agricultural production in different ways. During the already dry months, the decline of precipitation is likely to reduce the resilience of some plants (Vanacker et al. 2005). This is especially true for many ecosystems in Sub-Saharan Africa, particularly grass and shrub savannahs, which are shown to be highly sensitive to short-term availability of water due to climate variability (Vanacker et al. 2005). While the ranges of species may shift as a result of changing climate, this shift may probably not be in cohesive and intact units and are likely to become more fragmented (Channell and Lomolino 2000). This stimulates interest in understanding the effects of climate change on the potential for rain-fed agriculture for particular regions where this practice has important economic and social implications.

While observed and measured data increasingly support predictions of a warmer world in the next 50 - 100 years, the impact of rising temperatures on rainfall distribution patterns in the semi-arid tropics of Africa remain far less certain (Cooper et al. 2009). African countries are particularly vulnerable to climate change because of their dependence on rain-fed agriculture, low economic power, low levels of human and physical capital, and poor infrastructure (Nelson 2009). The negative effects of climate change on agricultural production are especially pronounced in Sub-Saharan Africa because of the significant contribution of the agricultural sector to the GDP, export earnings, and employment (Fan et al. 2009).

Cameroon, like many countries in sub-Saharan Africa has a high share of total poverty in the rural sector and a high share of GDP growth originating in agriculture (De Janvry 2009). Less than 1 percent of total agricultural land area in Cameroon is equipped for irrigation 
(FAOSTAT 2010). Small-scale food crop production in Cameroon's savanna zones is heavily dependent on timing and length of the rainy season. The timing and length of the rainy season is strongly dependent on and directly influenced by the movement of the Intertropical Tropical Convergence Front. This subjects the region to a pronounced seasonality with four to six months of rainy season in which most of the rain-fed food crop production takes place and six to eight months of dry season with no opportunities for non-irrigated food production (Yengoh et al. 2011). Food production among small-scale farmers is therefore very dependent on the reliability of the onset of rains and the distribution of rainfall during the rainy season (Yengoh et al. 2010) and rain-fed agriculture is one of the most vulnerable livelihood and economic sectors to climate change in the these regions. Since 1960, four major droughts and two floods have affected different parts of Cameroon's savanna zones with considerable effects on food production and human well-being (CRED 2011). The frequency of weather-related crop failures in Cameroon's savanna zones points to the vulnerability of food production in this region to future climate change. On a larger context, the vulnerability of this region mirrors the situation of the country's socio-economic life to forces of climate because of the importance of this region as a major production zone for cereals, pulses and livestock (Yengoh et al. 2011).

While installed irrigation capacity is generally low in Sub-Saharan Africa compared to that of many other regions (FAOSTAT 2010), climate change may further worsen the irrigation water supply reliability in areas with installed irrigation infrastructure (Nelson 2009). An appreciation of the expected impact of climate change to agricultural communities dependent on rain-fed production can guide policy-makers in designing strategies for mitigation and adaptation (Yengoh et al. 2010).

In this study, the CROPWAT model (Clarke et al. 1998) is used to compute crop water requirements and yield reduction due to soil moisture stress for the Guinea- and Sudan Savanna agro-ecological zones of Cameroon for baseline climate conditions (1961-1990) as well as three scenarios from the Special Report on Emissions Scenarios (SRES). Tools of geographical information systems are used to estimate the impact of climate change on the potential area for rain-fed agriculture and crop water requirements of five main food crops in this region. The goal of the analysis is to assess the impact of climate change at finer scales and explore avenues for adaptation. Besides assessing the impact of climate change on yield reduction, we estimate the crop area that will be suitable for the cultivation of major food crops of the region under different water requirement situations. The results are used to discuss the implications for agricultural planning at national, regional and farm level, as well as implications on the vulnerability of small-scale farmers. Based on such implications, a climate change adaptation portfolio for small-scale farming systems for savanna zones of Sub-Saharan Africa is proposed. This study complements others that assess the impact of climate change at country and regional level (Parry et al. 2004, Molua and Lambi 2006, Iglesias et al. 2007, Morton 2007).

\section{Description of study area}

The study area is located between latitude $6{ }^{\circ} \mathrm{N}$ and $13^{\circ} \mathrm{N}$ (Figure 1). This region covers an area of about $163513 \mathrm{Km}^{2}$ and makes up more than 35 percent of the total area of the country, $475500 \mathrm{Km}^{2}$. It comprises the Guinea- and Sudan-Savanna agro-ecological zones of the country and is the seat of most of the country's food crops and livestock production (Yengoh et al. 2011). This zone is interesting as a case study because its agro-ecological 
characteristics, farming systems and the economic situation of farmers here can be seen in large swaths of the continent, from Guinea in the west to Ethiopia in the East. Knowledge of production constraints as well as issues of mitigation and adaptation in this study area can therefore be applicable to similar regions in Sub-Saharan Africa.

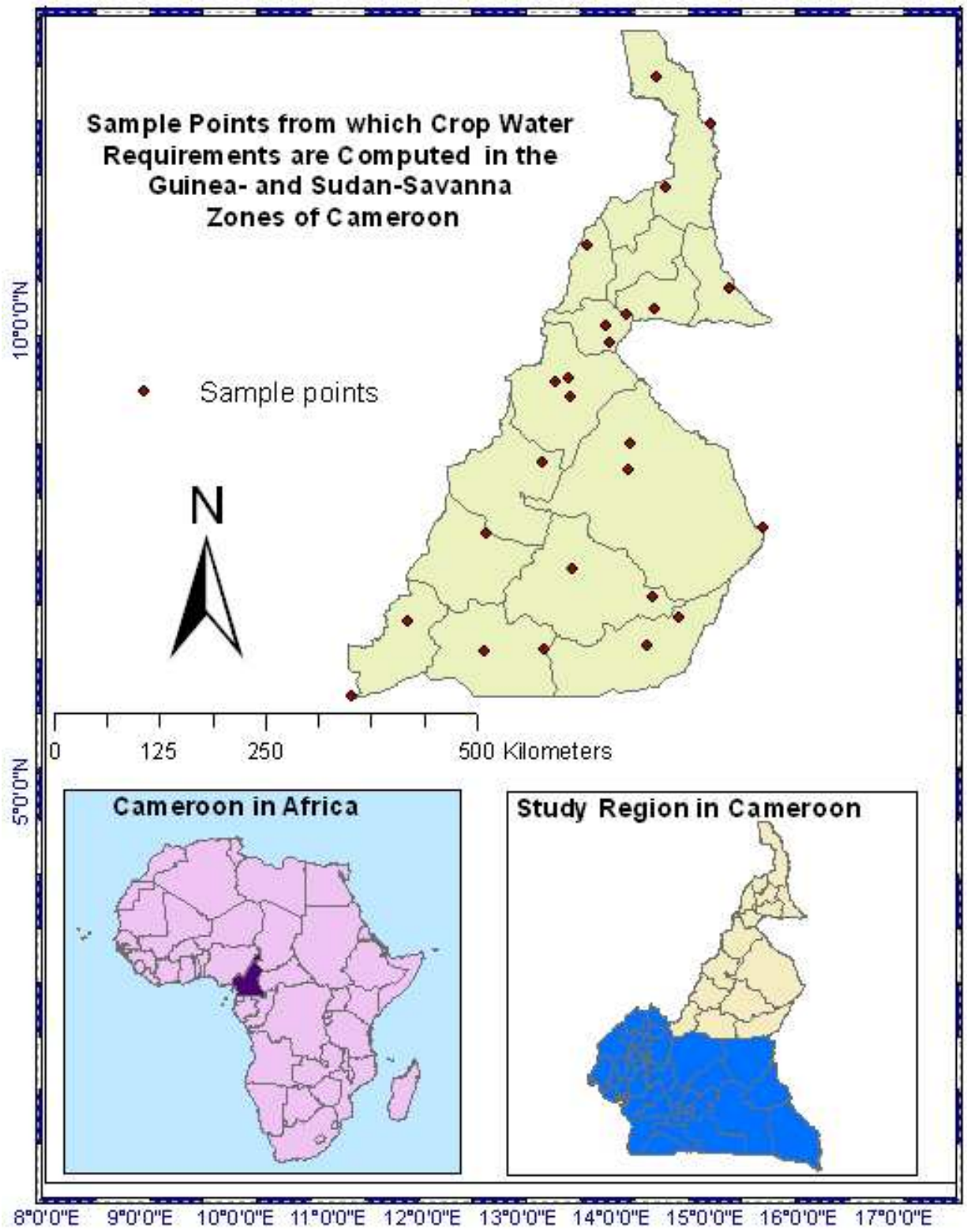

Fig. 1. Location of the study area. 
Rainfall varies between $1200 \mathrm{~mm}$ and $2300 \mathrm{~mm}$ annually around latitude $6^{\circ} \mathrm{N}$ to about 850 $\mathrm{mm}$ annually in the neighborhood of latitude $13{ }^{\circ} \mathrm{N}$. Population density is low in the southern parts of the region, at 13 and 20 persons per $\mathrm{km}^{2}$ in the Adamawa and North administrative regions respectively and 88 persons per $\mathrm{km}^{2}$ in the Far North administrative region (above latitude $10^{\circ} \mathrm{N}$ ). The national average population density is approximately 38 persons per $\mathrm{km}^{2}$. Agriculture is the main economic activity in Cameroon, practiced by more than 80 percent of the working population and contributing to $>45$ percent of GDP (Laux et al. 2010).

\section{Sources of data and analysis methods}

We use monthly climate data from the National Meteorological Service of Cameroon in Douala. These data which become inputs into the CROPWAT model for the computation of crop water requirements include temperature, humidity, wind speed and sunshine. For nine out of the twenty-five stations where such station data is absent, New LocClim is used to derive values for these areas by interpolation (see appendix for list and location of stations). New LocClim is a tool, capable of producing average monthly climate values (up to eight variables) taken from the agro-climatic database of the Agromet Group of the Food and Agriculture Organization of the United Nations (Grieser et al. 2006). Besides allowing for an extensive investigation of interpolation errors, and the influence of different settings on the results, New LocClim also allows for the optimization of the interpolation with respect to the data analyzed. Average monthly temperature and rainfall for three SRES emission scenarios for 2050s are derived from the HadCM3 model of the Hadley Centre for Climate Prediction and Research, Meteorological Office, United Kingdom.

The data is used to calculate crop water requirements using CROPWAT 8.0 for Windows. CROPWAT is a decision support system developed by the Land and Water Development Division of the Food and Agriculture Organization of the United Nations Organization to calculate potential evapotranspiration, crop water requirements and crop irrigation requirements (Clarke et al. 1998). Procedures for calculating variables for crop water requirements used in CROPWAT are based on FAO guidelines extensively presented in the publication No. 56 of the Irrigation and Drainage Series of FAO "Crop Evapotranspiration Guidelines for computing crop water requirements" (Allen et al. 1998). CROPWAT has been used extensively for computing crop water requirements for different crops, case studies and at different scales (Molua and Lambi 2006, Iglesias et al. 2007, Traore et al. 2007, Stancalie et al. 2010).

We begin by calculating crop water requirements for 27 stations using climate data for baseline conditions for 1961-1990. Then baseline rainfall and temperature data is replaced with data from the HadCM3 model output. This allows for the calculation of simulated conditions of evapotranspiration, and effective rainfall based on rainfall and temperature conditions of the 2050s. While we assume constant relative humidity, wind speed and number of hours of sunshine, radiation changes with the introduction of new temperature values during the calculation of evapotranspiration using modeled data. Crop water requirements are calculated for three SRES story-lines: the moderate, mid-level A1B carbon scenario, the higher, more extreme A2 carbon scenario, and the more optimistic B1 carbon scenario. These story-lines are alternative images of how the future might unfold (IPCC 2007).

Crop water requirements for baseline, A2, A1B, and B1 scenarios are then interpolated on the study area using inverse distance weighting (IDW) with ArcEditor 9.3. The choice of 
IDW was made because this interpolation method provides a simple way of guessing the values of a field at locations where no measurement is available. It estimates unknown measurements as weighted averages over the known measurements at nearby points, giving the greatest weight to the nearest points. IDW is therefore ideal in obtaining a smooth surface whose value at any point is more like the values at nearby points than the values at distant points (Longley 2005). In calculating the potential area for rain-fed crop production potential, land occupied by a number of land land-use types is eliminated. These include land occupied by urban and rural settlements, protected areas, swamps, water bodies and land occupied by irrigated agriculture.

Yield reduction due to soil moisture stress is expressed as a percentage of the maximum production achievable in the area under optimal soil moisture conditions. It is computed with reference to the whole growing season based on (Allen et al. 1998, Clarke et al. 1998):

$$
(1-\mathrm{Ya} / \mathrm{Ymax})=\mathrm{K} y(1-\mathrm{ET} c \text { adj } / \mathrm{ET} c)
$$

$\mathrm{Ya}=$ Yield achievable under actual conditions

Ymax = Maximum crop yield achievable in case of full satisfaction of crop water needs

Ky $\quad=$ Yield response factor

ETc adj = Crop evapotranspiration under non-standard conditions

Etc $=$ Crop evapotranspiration under standard conditions

A choice of five crops, (all of which are important for farmers in this region) is used to assess the effects of climate change on the potential for rain-fed agriculture in Cameroon's savanna zones.

Beans are the main source of non-animal protein among resource poor farmers, have a short growing cycle and are cultivated widely among small-holder farmers. Surpluses are sold in local markets and end up in markets in the south of the country.

Groundnuts are an important source of cooking oil in the savanna zones where oil palms do not grow. Together with beans, they have a short growing cycle, are widely cultivated, and help boost soil nitrogen levels. Besides being widely used on traditional foods, groundnuts are also a very important export crop. Producers in the Far North Region sell to buyers from Nigeria, Chad and the Central African Republic.

Maize has, over the last decade been replacing millet as the stable food in some traditional diets of the region. Besides, its growing importance as a food crop, the relatively high yields of maize, relative to the millet it is replacing and the steady demand fueled by consumption both within and out of the country is giving maize and increasing importance in the region. Potatoes are seen as local luxury food stuff with high demand from both local buyers and merchants from neighbouring countries. Recently introduced into the region, potato cultivation is growing rapidly.

Sorghum remains one of the main food crops among most communities in this part of the country. It continues to command both local and foreign demand and so is widely grown.

\section{Results and discussion}

\subsection{Yield reduction due to soil moisture stress}

Mean yield reduction due to soil moisture stress is greater for all crops in the A1B and A2 scenarios relative to the baseline (Figure 2). Potato shows the greatest mean yield reductions of 4.1 percent and 7.7 percent for the $\mathrm{A} 1 \mathrm{~B}$ and $\mathrm{A} 2$ scenarios respectively and 1.5 percent for 
the B1 scenario. The mean yield reduction for potato in the baselines scenario is 2.3 percent. The relatively drier conditions of the Sudan-savanna zone in the far north of the study area severely restricts the cultivation of potato and accounts for this high mean reduction in yields. In these parts of the country, maximum yield reductions of up to 35.2 and 50.4 percent are obtained in the A1B and A2 scenarios respectively (Figure 2). This is followed by bean, with mean yield reductions of 3.4 percent for the A1B scenario 7.2 percent for A2 and 0.6 percent for the B1 scenario. The largest maximum yield reductions are observed in bean, 36.7 and 55.1 percent for the $\mathrm{A} 1 \mathrm{~B}$ and $\mathrm{A} 2$ scenarios respectively. While maize and groundnuts reveal lower mean and maximum yield reductions compared to potatoes and beans, sorghum has the least reductions in yield, 0.6 and 1.9 percent in the A1B and A2 scenarios respectively. In the baseline and the B1 scenario, the yield reduction is negligible (Figure 2). All crops serve the dual purpose of household consumption and income generation from surpluses. However, some crops are more important for income generation, such as potato, groundnuts and beans, and are more heavily impacted by yield reduction that those required for basic household food supply, sorghum and maize.
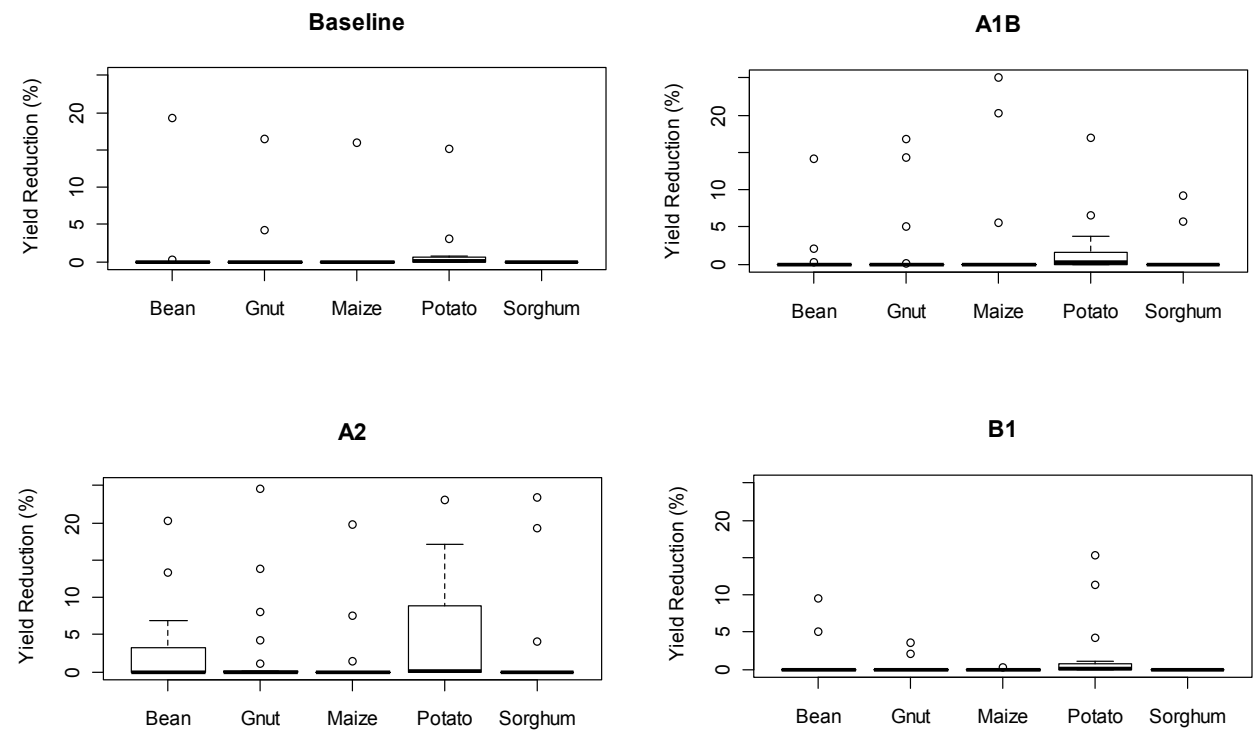

Fig. 2. Yield reduction due to soil moisture stress for all crops and scenarios. Notice the large variations resulting from differences in agro-climatic resources between the Guinea- and Sudan-savanna agro-ecological zones. Also see Appendix 1 for a table of the descriptive statistics.

While the study area is collectively described as the savanna zone of Cameroon, some parts of this zone are marginal in their agricultural production potential. In the Sudan-Savanna agro-ecological zone (above latitude $12 \mathrm{~N}$ ), the short rainy season of only about three months, loose sandy soils, and high temperatures impose problems of agricultural water availability which reduce crop production potential here. Crop production potential in this 
agro-ecological zone is therefore in a precarious balance based on these water-related constraints to the length of the growing season, the soil's water-holding capacity, rates of crop evapotranspiration, and others. Small changes in temperature, as well as the amount or pattern of precipitation may result in these zones tipping over to areas of limited crop production potential. The high maximum reduction in yields resulting from soil moisture stress in the A1B and the A2 scenarios is attributed to the steep decline of crop productivity in the Sudan-Savanna agro-ecological zone due to such changes in temperature and precipitation changes forecasted for these scenarios. For maize and sorghum, much of the area which was formerly favorable for rain-fed production becomes unfavorable (requiring irrigation for optimal yields without water stress).

Other studies have established relationships between climate change and yields at different levels and different time scales. Ex-post statistical analysis of relationships between growing season temperature, precipitation and global average yield for six major crops, estimated that warming since 1981 has resulted in annual combined losses of 40 million tons or US\$5 billion (Lobell and Field 2007). Using two scenarios of future temperature increases $\left(1.5^{\circ} \mathrm{C}\right.$ from MAGICC/SCENGEN model and $3.6^{\circ} \mathrm{C}$ rise from Global Circulation Model results), previous studies have predicted a reduction in wheat grain and other field crops yield of up to 30 percent and increase in its water needs of about 3 percent (El-Shaer et al. 1997, Eid and El-Mowelhi 1998) in Egypt by the year of 2050. Studies using crop simulation models such as CropSyst also forecasts yield reductions in Egyptian grain wheat by 2038 (Khalil et al. 2009). Sub-Saharan Africa is increasingly being corroborated as being the region with the most effects of climate change on yield reduction. By using an integrated approach to analyze the correlation between historical crop yield and meteorological drought, Africa emerges with the highest drought risk index (from 95.77 at present to 205.46 in 2100), with yield reductions increasing accordingly by $>50$ percent in 2050 and almost 90 percent in 2100 (Li et al. 2009). Average rice, wheat and maize yields are forecast to decline by up to 14 percent, 22 percent, and 5 percent, respectively, in Sub-Saharan Africa as a result of climate change (Nelson 2009). It is estimated that yield reductions of up to 50 percent may be experienced for some crops by 2020 (Boko 2007).

\section{Fall in area with potential for rain-fed agriculture}

Under baseline conditions, sorghum and maize offer the greatest opportunities for rain-fed cultivation. The potential is low for bean and groundnuts and inexistent for potatoes. The amount of area with potential for rain-fed agriculture falls considerably for sorghum and maize, especially for the baseline scenario relative to the A1B and A2 scenarios (Figure 3). This emphasizes the idea of certain agro-ecological zones being in a precarious balance in relation to crop water requirements discussed previously. The precarious balance of agricultural water conditions for the cultivation of rain-fed maize and sorghum is offset by precipitation and temperature changes resulting from climate change by the middle of the century. The outcome is a significant fall in the amount of area with rain-fed potential for the cultivation of sorghum and maize.

The area with rain-fed potential for bean increases in the B1 scenario relative to the baseline but also fall for the A1B and A2 scenarios. A fall in the potential area for the rain-fed cultivation or its absence does not however mean that these crops are not being cultivated anyways. It indicates that based on the water requirements of these crops, maximum obtainable yields cannot be achieved without irrigation (Clarke et al. 1998). The amount of 
area with the potential for rain-fed cultivation of different crops in the baseline scenario relative to the total cultivable area is sorghum (79.47 percent), potato (0 percent), maize (39.48 percent) groundnuts (2.3 percent), and bean (4.28 percent). This points water availability being an important constraint to food crop production in this region even at the present.
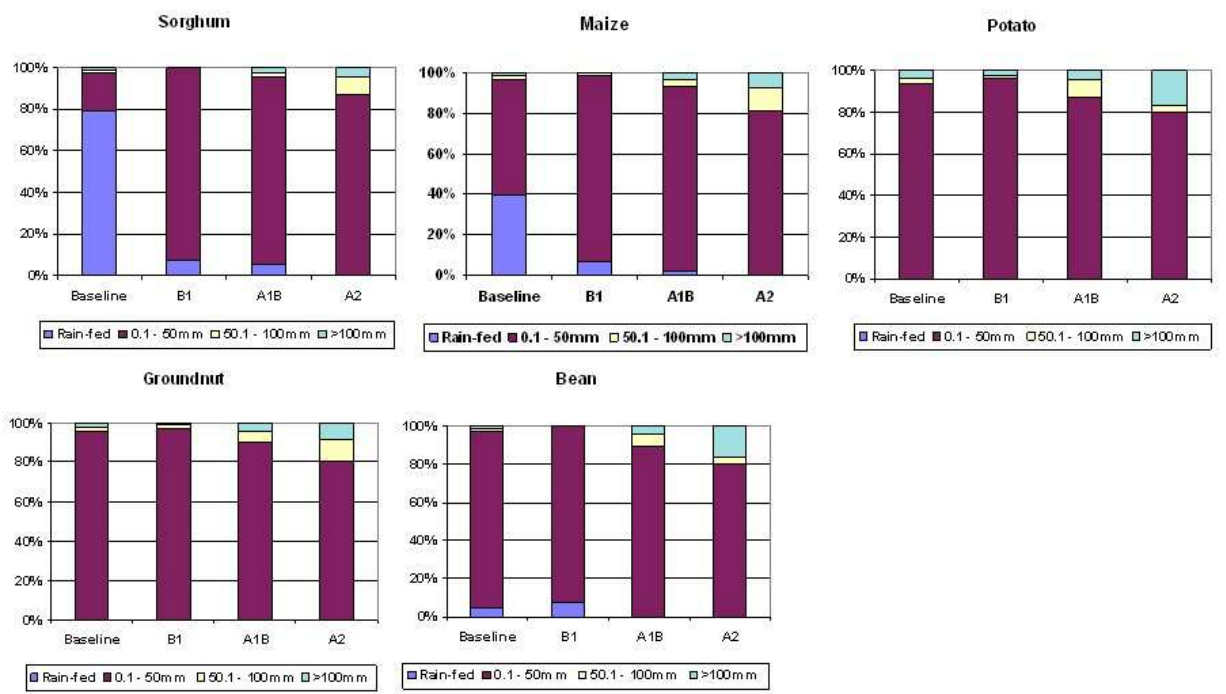

Fig. 3. Amount of land (in percent of total arable land) for cultivation under non-water stressed conditions of analyzed crops in the baseline conditions (1960-1990) and three climate scenarios for 2050 average conditions. The amount of land under different water requirements is visualized in three different intervals: rain-fed, $\leq 50 \mathrm{~mm}, 50.1-\leq 100 \mathrm{~mm}$, $\geq 100 \mathrm{~mm}$.

The low potential for rain-fed cultivation of potato, groundnut and beans even in the baseline scenario (Figure 3) also highlights the importance of water as an important element determining the yield of food crops in this region. This is especially important for food security at household level for two reasons.

1. Small-scale farmers who make up more than 90 percent of farmers in this region are heavily dependent on rain-fed food production.

2. The few economic resources of these small-scale farmers reduce their ability to invest in water-provision technologies to improve yields.

The above reasons may likely be reinforced by the effects of climate change. The average optimum temperature range for sorghum is $21^{\circ} \mathrm{C}$ to $35^{\circ} \mathrm{C}$ for seed germination, $26^{\circ} \mathrm{C}$ to $34^{\circ} \mathrm{C}$ for vegetative growth and development, and $25^{\circ} \mathrm{C}$ to $28^{\circ} \mathrm{C}$ for reproductive growth (Maiti 1996). Mean annual temperatures in Cameroon's savanna regions are $22.02^{\circ} \mathrm{C}, 27.95^{\circ} \mathrm{C}$, and $28.34^{\circ} \mathrm{C}$ for Ngoundere, Garoua and Maroua respectively with diurnal ranges of up to $13^{\circ} \mathrm{C}$. Given the strong seasonality, growing season temperatures ranges are between $7{ }^{\circ} \mathrm{C}$ and $10^{\circ} \mathrm{C}$. Mean annual temperature is projected to increase by about $1.0^{\circ} \mathrm{C}$ to $2.9^{\circ} \mathrm{C}$ by the $2060 \mathrm{~s}$ with 'hot' days occurring in 20-51 percent of days at this time (McSweeney et al. 2010). Such changes could have significant negative effects on the productivity of grain crops, including 
sorghum (Prasad et al. 2008). This may explain the significant fall in the area with rain-fed potential for sorghum and maize (Figure 3).

\section{Requirements for irrigated agriculture}

A majority of the area in Cameroon's savanna regions will be suitable for the cultivation of the five main crops being investigated if crop water requirements of up to $50 \mathrm{~mm}$ are met (Figure 3). With the exception of sorghum in which most of the land area is assessed to be suitable for rain-fed agriculture in the baseline, all other crops are suitable for cultivation on $>80$ percent of the land given irrigation of up to $50 \mathrm{~mm}$ (Figure 3). The potential area for the cultivation of crops under non-water stressed conditions given crop water satisfaction of both $50 \mathrm{~mm}-$ $100 \mathrm{~mm}$ and $>100 \mathrm{~mm}$ is low (Figure 3). This area increases however for all crops under the A1B and $\mathrm{A} 2$ scenarios relative to the baseline (Figure 4). With the exception of potato and beans in the $\mathrm{A} 2$ and $\mathrm{A} 1 \mathrm{~B}$ scenarios, less that 10 percent of the total area of Cameroons savanna will require irrigation of $>50 \mathrm{~mm}$ for the cultivation of any of the five crops.
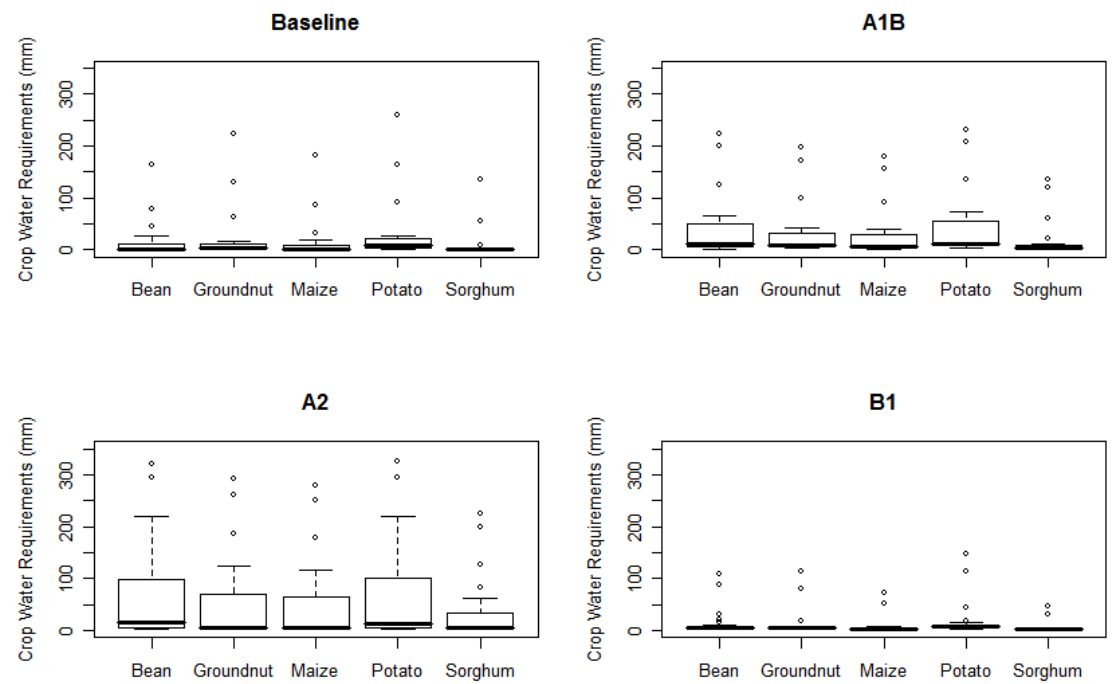

Fig. 4. Crop water requirements for all crops and scenarios.

Crop water requirements under different scenarios will however be different for different crops. Water requirements increase for all crops in the A1B scenario with the exception of sorghum (Figure 4). In the A2 scenario on the other hand, water requirements are appreciably higher for bean and potato, but generally high for all crops (including sorghum). Such requirements fall in the $\mathrm{B} 1$ scenario relative to the baseline for all crops (Figure 4).

\section{Implications for agricultural planning and the drive towards sustainable agriculture}

Concerns over human-induced land degradation, including a large-scale decline in soil fertility by 'soil mining' especially in sub-Saharan Africa have been raised (Mokwunye et al. 1996). The 
impact of climate change on the potential area for rain-fed agriculture will likely compound these challenges. Population growth, increase of urbanization and associated changes in dietary preferences contribute to increasing the production pressure on African agriculture. These challenges contribute to imposing substantial pressure for the transformation of agriculture in Sub-Saharan Africa. The impetus for such transformation will likely be the pressure of shrinking agricultural land in a continent whose demography and economics is arguably poised to transform significantly in the next few decades (Sanchez et al. 2009, Sánchez 2010). Evidence of such Boserupian drivers of change has been reported in many cases of agricultural transformations (Boserup and Kaldor 2005, Demont et al. 2007). Studies already point to the possibility of tripling yields per hectare with investments in the appropriate combination of governance and material resources within a framework of a strong commitment to sustainable organic agriculture (Sanchez et al. 2009, Sánchez 2010).

Priorities at national and regional level

The adoption of sustainable systems of agricultural intensification may therefore be necessary to meet the numerous food production challenges associated with this transformation (Davies and Chaves 2010). While some of such technologies like crop residue management, improved fallow, agro-forestry and others have proven successful in many parts of the world, their success in Africa will be seriously influenced by many of the peculiar socio-economic and political realities of this region (Yengoh et al. 2009).

The drive towards sustainable intensification is urged as an approach which can permit the more sustainable use of resources in agriculture, giving rise to higher water use efficiencies, more sustainable nutrient management, optimal use of available agricultural land and others (Baulcombe et al. 2009, Williams 2009). The attainment of sustainable implementation as a means of adapting to the need to increase food production while meeting challenges imposed by global environmental changes, changes in human demographics and culinary preferences also demand addressing non-biophysical challenges of small-scale farmers. The attainment of sustainable intensification calls for the dissemination and support for tested practices of sustainable agriculture (Table 1) which respond to the social, economic and cultural realities of would-be practitioners. For small-scale farmers in Sub-Saharan Africa, it also entails addressing problems associated with the economic and social context within which agriculture is practiced. Such measures should ideally address three key issues:

- Make agriculture profitable enough for farmers to be able to afford alternative means of fertilization, farm clearing and the provision of forage for livestock.

- Provide affordable access to the resources and information necessary for adapting more sustainable techniques in agriculture.

- Develop agricultural governance structures at local level and ensure their effectiveness by eliminating setbacks like corruption and administrative red-tape in the implementation of sustainable agriculture projects.

Priorities at farm level

Besides an increase in atmospheric temperatures of between $1.4^{\circ} \mathrm{C}$ to $5.8^{\circ} \mathrm{C}$, climate change is expected to bring greater variability in some climatic event that are important for food crop production (IPCC 2007). These include events such as the increased frequency of short episodes of extreme temperatures increases and associated stresses to crops (IPCC 2007). Farmers may have to revise their structure of decision-making to accommodate an increasingly variable climate. There will be a need for resilience in decision-making with 
regards to choice of crop-types to cultivate on a season-to-season basis, the timing of farm operations, the choice of systems to improve water availability and use, method of erosion control, and other production-related decisions. Short- and medium-term decisions on food production would have to be made on-the-fly based on weather and climate forecasts in a new order of increased climate variability.

\begin{tabular}{|c|c|c|}
\hline $\begin{array}{l}\text { Sustainable } \\
\text { practice }\end{array}$ & Agro-ecological goals & $\begin{array}{l}\text { Benefits for small-scale farming } \\
\text { systems }\end{array}$ \\
\hline $\begin{array}{l}\text { Crop residue } \\
\text { management }\end{array}$ & $\begin{array}{l}\text { - Optimize benefits from } \\
\text { multifunctional uses of crop } \\
\text { residues } \\
\text { - Improve soil organic matter }\end{array}$ & $\begin{array}{l}\text { Naturally decaying residues improve } \\
\text { soil organic matter structure and } \\
\text { content (Moyin-Jesu 2007). Residues } \\
\text { may serve other purposes like being } \\
\text { used for animal feed or straw }\end{array}$ \\
\hline Agro-forestry & \begin{tabular}{|l|} 
- Introduce multifunctional trees \\
into agro-ecosystems \\
- Improve agro-ecosystem resilience \\
\end{tabular} & $\begin{array}{l}\text { Agricultural risk is diversified as } \\
\text { agro-ecosystems become more } \\
\text { resilient (Wojtkowski 2008). The } \\
\text { system offers other needed products } \\
\text { besides food like firewood \& forage. It } \\
\text { is effective in restoring disturbed land } \\
\text { (Peng et al. 2009) }\end{array}$ \\
\hline $\begin{array}{l}\text { Integrated } \\
\text { water } \\
\text { management }\end{array}$ & \begin{tabular}{|l|} 
- Sustain plant water availability for \\
longer periods \\
- Improve on plant water use \\
efficiency
\end{tabular} & $\begin{array}{l}\text { Minimizes the problem of increasing } \\
\text { scarcity of water for agricultural } \\
\text { purposes and improves water } \\
\text { productivity (Tenywa and Bekunda } \\
\text { 2009) }\end{array}$ \\
\hline $\begin{array}{l}\text { Integrated } \\
\text { pest } \\
\text { management }\end{array}$ & $\begin{array}{l}\text { - Control pests and diseases } \\
\text { - Minimize/eliminate the use of } \\
\text { pesticides }\end{array}$ & $\begin{array}{l}\text { Increases agricultural biodiversity } \\
\text { both in the soil and above ground. } \\
\text { Reduces the risk of environmental } \\
\text { pollution from pesticide use } \\
\text { (Baulcombe et al. 2009) }\end{array}$ \\
\hline $\begin{array}{l}\text { Integrated } \\
\text { nutrient } \\
\text { management }\end{array}$ & $\begin{array}{l}\text { - Generate nutrients within farm } \\
\text { systems } \\
\text { - Minimize/eliminate dependence } \\
\text { on external nutrient sources }\end{array}$ & $\begin{array}{l}\text { Plant residue can become inputs into } \\
\text { composting systems for organic } \\
\text { fertilizers (Moyin-Jesu 2007). } \\
\text { Optimizes the flow of farm-scale } \\
\text { biogeochemical processes }\end{array}$ \\
\hline $\begin{array}{l}\text { Conservation } \\
\text { tillage }\end{array}$ & $\begin{array}{l}\text { - Conserve soil structure } \\
\text { - Improve on the flow of } \\
\text { biogeochemicals }\end{array}$ & $\begin{array}{l}\text { Naturally decaying residues improve } \\
\text { soil organic matter structure and } \\
\text { content (Moyin-Jesu 2007). }\end{array}$ \\
\hline $\begin{array}{l}\text { Livestock } \\
\text { integration }\end{array}$ & \begin{tabular}{|l|} 
- Generate nutrients within farm \\
systems \\
- Improve the system \& efficiency of \\
nutrient cycling \& flows
\end{tabular} & $\begin{array}{l}\text { Creates a system that is less } \\
\text { dependent on outside sources of } \\
\text { fertilizers \& more resilient to food } \\
\text { crop natural and price fluctuations }\end{array}$ \\
\hline $\begin{array}{l}\text { Integrated } \\
\text { erosion } \\
\text { management }\end{array}$ & $\begin{array}{l}\text { - Conserve soil structure } \\
\text { - Conserve the top soil \& soil organic } \\
\text { matter }\end{array}$ & $\begin{array}{l}\text { Sustains soil fertility and productivity } \\
\text { (Baulcombe et al. 2009) }\end{array}$ \\
\hline
\end{tabular}

Table 1. The contribution of sustainable agricultural practices in enhancing farmland productivity among small-scale farmers. 


\section{Implications for the vulnerability of small-scale farmers}

Climate change is expected to increase global net crop irrigation requirements by 5-8 percent by 2070, with considerable regional variation (Döll 2002). The vulnerability of agriculture, like most other sectors in Sub-Saharan Africa is aggravated by the interaction of multiple stressors affecting the sector at different levels (Boko 2007). The estimated increase of $5-8$ percent in the proportion of arid and semi-arid lands on the continent (Boko 2007) points to a future with reduced input of precipitation especially for the savanna regions which buffer the already dry African Sahel. The situation in Cameroon's savanna zone is a mirror of what can be found in many parts of the continent. Small-scale farmers continue to practice food production notwithstanding the reduction in yields imposed by water stress. While semiarid conditions are already imposing challenging conditions for food production among many small-scale farmers, it is estimated that yield reductions of up to 50 percent may be experienced by 2020 (Boko 2007). Studies warn of impending global problems associated to food security and access to water if appropriate action is taken to improve water management and increase water use efficiency (Falkenmark and Rockström 2008, Ringler et al. 2010).

Stagnation in land and agricultural productivity in sub-Saharan Africa, and hence the slow drive towards attaining food security goals is attributed to two main factors: lack of expansion of area under irrigation and limited use of chemical fertilizers (De Janvry 2009, Jayne et al. 2010). While the donor community aspires to replicate the success of irrigation projects from other regions of the world to benefit agriculture in Sub-Saharan Africa, the scale of need involves overcoming some huge challenges. These include issues related to the choice of technology, competition for water between sectors, a relative lack of water management expertise, the cost of maintaining and replacing worn out equipment; uncertain markets and related barriers; and the uncertainties of Sub-Saharan African weather (Lankford 2009).

At the level of farmers, adaptation may take the form of either changing or increasing their use of farm inputs with which they are already familiar (factor substitution), or adopt new technologies and production methods through a learning process (Binswanger and Pingali 1988). The availability of new technology does not however mean instant adoption. The process of technology adoption among small-holder farmers in Sub-Saharan Africa is a complex one involving the interplay of many complex drivers (Yengoh et al. 2009). The effects of adaptation to climate change on yields are expected to be different for different regions. With adaptation in the low latitudes, the yields of maize, wheat and rice maintains at current levels given temperature changes of +1 to $+2^{\circ} \mathrm{C}$. At changes of +2 to $+3^{\circ} \mathrm{C}$, adaptation maintains yields of all crops above baseline. At this range, yields drop below baseline for all crops without adaptation. At changes of +3 to $+5^{\circ} \mathrm{C}$, yields of major crops like maize and wheat are reduced below baseline regardless of adaptation, but adaptation maintains rice yield at baseline levels (Easterling et al. 2007).

\section{Equipping small-scale farming systems in savanna regions of Sub- Saharan Africa to face challenges of climate change and variability}

The challenge of equipping small-scale, farming communities to face agricultural water shortages resulting from climate entails developing a mitigation portfolio which addresses key aspects of mitigation preparedness. These key components are access to appropriate 
resources, the presence of a clearly thought out strategy, at cooperation in information development, knowledge and skill sharing (Figure 5). These components are essential in addressing key social, economic and knowledge gaps of small-scale farming communities in the Sub-Saharan savanna.

\begin{tabular}{|c|c|c|}
\hline Resources & Strategy & Cooperation \\
\hline $\begin{array}{l}\text { Financial } \\
\begin{array}{l}\text { Credit access for small-scale farmers; Capital for rural } \\
\text { infrastructure development }\end{array}\end{array}$ & $\begin{array}{c}\text { Responsibilities } \\
\text { Clear delineation of roles and responsibilities at national, regional } \\
\text { and local levels }\end{array}$ & $\begin{array}{c}\text { Inter-regional Knowledge Transfer } \\
\text { Communities with threats learning from those with known } \\
\text { adaptation skills }\end{array}$ \\
\hline $\begin{array}{l}\text { Institutional } \\
\text { Strong legal framework; Accountability of public institutions; } \\
\text { Stable political institutions }\end{array}$ & $\begin{array}{l}\text { Project Analysis } \\
\text { Strengths, Weakness, Opportunities and Threats (SWOT) analysis } \\
\text { of activities on a project-by-project basis }\end{array}$ & $\begin{array}{c}\text { Bottom-Up Cooperation } \\
\text { Bottom-up cooperation in the design \& management of mitigation } \\
\text { strategies }\end{array}$ \\
\hline $\begin{array}{l}\qquad \underline{\text { Social }} \\
\text { Working land tenure system; Gender equality; Social services }\end{array}$ & $\begin{array}{l}\text { Prioritization } \\
\text { Prioritizing projects that strive for risk-reduction within the } \\
\text { context of sustainable development planning }\end{array}$ & $\begin{array}{l}\text { Cooperation Across Disciplines } \\
\text { Cross-disciplinary knowledge development \& sharing }\end{array}$ \\
\hline $\begin{array}{l}\text { Information \& Technology } \\
\begin{array}{l}\text { Knowledge on existing threats \& available opportunities; Trained } \\
\text { personnel; Locally compatible skills \& technologies }\end{array}\end{array}$ & $\begin{array}{l}\text { Protection } \\
\text { Protect small-scale farmers from unfair competition with } \\
\text { subsidized farm products from the developed world }\end{array}$ & $\begin{array}{c}\text { North-South Cooperation } \\
\text { Cooperation in Technology Development \& Transfer }\end{array}$ \\
\hline
\end{tabular}

Fig. 5. Components of climate change adaptation portfolio for small-scale farming systems in savanna zones of Sub-Saharan Africa.

In Cameroon and many countries in the regions, a number of obstacles challenge the development of each of the components in this climate change mitigation portfolio.

1. Resources:

Access to financial, institutional, social and information resources are necessary to plan, implement and sustain adaptation efforts. Financial resources are inadequate, and investment in credit systems for small-scale farmers or development of rural infrastructure is limited. The absence of a strong legal system breeds and perpetuates the proliferation of corruption and lack of public accountability at different levels of governance. Where political instability prevails, resources cannot be marshaled for purposes of enhancing mitigation, since people strive to survive on a day to day basis. While many Cameroonians increasingly question the fairness and representation of the democratic in their country, Cameroon has remained an island of relative peace in a continent troubled by many different forms of political strife. The land tenure system remains largely based on traditional cultures with small-scale farmers having virtually no formalized rights to landed property their families have owned for several generations. Social safety nets are very limited and reduce risk-taking in production decisions among small-scale farmers.

2. Strategy:

The importance, urgency and scale of threats posed by climate change on agriculture demands careful strategizing. Strategies should develop a clear road-map which addresses different scales and factors for achieving desired mitigation goals. They should also address the distribution of responsibilities and identify projects to meet desired short- and long-term objectives. There is need to prioritize projects and activities towards attaining the desired level of mitigation based on the availability of 
human and technological resources. Agricultural policies in OECD countries are seen to damage agricultural production in developing countries. Small-scale farmers in developing countries are unlikely grow and attain different goals of sustainability if they continue to compete subsidized products from the developed world. Notwithstanding the insufficiencies of small-scale farming systems in Sub-Saharan Africa, world trade reform in some crops stand a good chance of benefiting many of the small-scale farmers of the region (Jayne et al. 2010). A level of protection for the smallscale farmers is needed in the face of subsidies of agricultural products from the developed world to create an environment in which small-scale farmers can expand their output, profits and viability.

3. Cooperation:

Cooperation between regions and cultures in sharing experiences and knowledge on different aspects of mitigation can be very useful (Yengoh et al. 2010). In order to meet the challenge of integrating different sectors that relate to and influence small-scale farming systems, there is need for cooperation across disciplines and socio-economic sectors. A bottom-up approach ensures that the outcomes of climate change mitigation efforts respond to the needs of those truly in need (the small-scale farmers at local level). The need for cooperation at international level in knowledge development and resources transfer has been raised as important in assisting systems of developing countries in their drive towards developing mitigation strategies and adapting to climate change.

\section{Conclusion}

Cameroon's savanna regions do not offer the full potential for rain-fed production for some of the crops studied in this area. In the baseline scenario, the potential is especially low for potatoes, groundnuts and beans, and relatively high for sorghum and maize. This potential area for rain-fed production falls considerably for sorghum and maize by 2050 in the A2, A1B and B1 SRES scenarios relative to the baseline (1961-1990). By meeting crop water requirements of up to $50 \mathrm{~mm}$ the greatest amount of area in which maximum obtainable yields (in the absence of water stress) can be expected for all crops studied is achieved in all SRES scenarios. Mean yield reduction due to soil moisture stress is greatest for potato, maize and bean, especially in the A2 and A1B scenarios. National and regional level planning should accelerate the process of introducing and up-scaling tested processes and practices of agricultural intensification. At the farm level, decision-making should become more resilient, capable of changing at short and medium scales to accommodate new climate related adaptive imperatives. The adaptation portfolio of small-scale farmers in Cameroon's savanna regions should comprise of three groups of components: the necessary resources for adaptation, a clear strategy of response with carefully shared responsibilities for meeting prioritized targets, and an indispensable cooperation strategy.

\section{Supplementary material}

Appendix 1. Descriptive statistical table of yield reduction due to soil moisture stress for the study region. It is expressed as a percentage of the maximum production achievable in the area under optimal conditions. 


\begin{tabular}{|c|c|c|c|c|c|c|}
\hline Baseline Scenario & Minimum & Maximum & Mean & Median & Standard Deviation & Standard Error \\
\hline Bean & 0.0 & 19.2 & 0.8 & 0.0 & 3.8 & 0.8 \\
\hline Groundnut & 0.0 & 16.4 & 0.8 & 0.0 & 3.4 & 0.7 \\
\hline Maize & 0.0 & 16.0 & 0.6 & 0.0 & 3.2 & 0.6 \\
\hline Potato & 0.0 & 34.5 & 2.3 & 0.1 & 7.4 & 1.5 \\
\hline Sorghum & 0.0 & 0.0 & 0.0 & 0.0 & 0.0 & 0.0 \\
\hline \multicolumn{7}{|l|}{ Scenario A1B } \\
\hline Bean & 0.0 & 36.7 & 3.4 & 0.0 & 9.8 & 2.0 \\
\hline Groundnut & 0.0 & 16.7 & 1.4 & 0.0 & 4.4 & 0.9 \\
\hline Maize & 0.0 & 25.1 & 2.0 & 0.0 & 6.3 & 1.3 \\
\hline Potato & 0.0 & 35.4 & 4.1 & 0.2 & 9.6 & 1.9 \\
\hline Sorghum & 0.0 & 9.1 & 0.6 & 0.0 & 2.1 & 0.4 \\
\hline \multicolumn{7}{|l|}{ Scenario A2 } \\
\hline Bean & 0.0 & 55.1 & 7.2 & 0.0 & 15.6 & 3.1 \\
\hline Groundnut & 0.0 & 27.2 & 3.2 & 0.0 & 7.5 & 1.5 \\
\hline Maize & 0.0 & 45.8 & 4.6 & 0.0 & 12.3 & 2.5 \\
\hline Potato & 0.0 & 50.4 & 7.7 & 0.1 & 14.8 & 3.0 \\
\hline Sorghum & 0.0 & 23.4 & 1.9 & 0.0 & 5.9 & 1.2 \\
\hline \multicolumn{7}{|l|}{ Scenario B1 } \\
\hline Bean & 0.0 & 9.5 & 0.6 & 0.0 & 2.1 & 0.4 \\
\hline Groundnut & 0.0 & 3.6 & 0.2 & 0.0 & 0.8 & 0.2 \\
\hline Maize & 0.0 & 0.2 & 0.0 & 0.0 & 0.0 & 0.0 \\
\hline Potato & 0.0 & 15.3 & 1.5 & 0.1 & 3.7 & 0.7 \\
\hline Sorghum & 0.0 & 0.0 & 0.0 & 0.0 & 0.0 & 0.0 \\
\hline
\end{tabular}

Appendix 2. Combined maps of potential area for the cultivation of different crops given different crop water requirements (derived from interpolation).

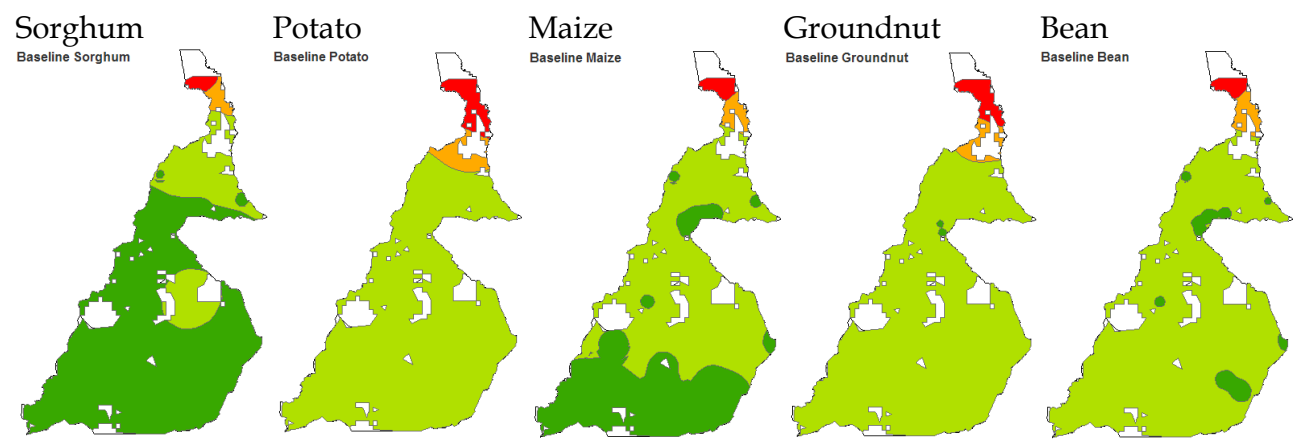



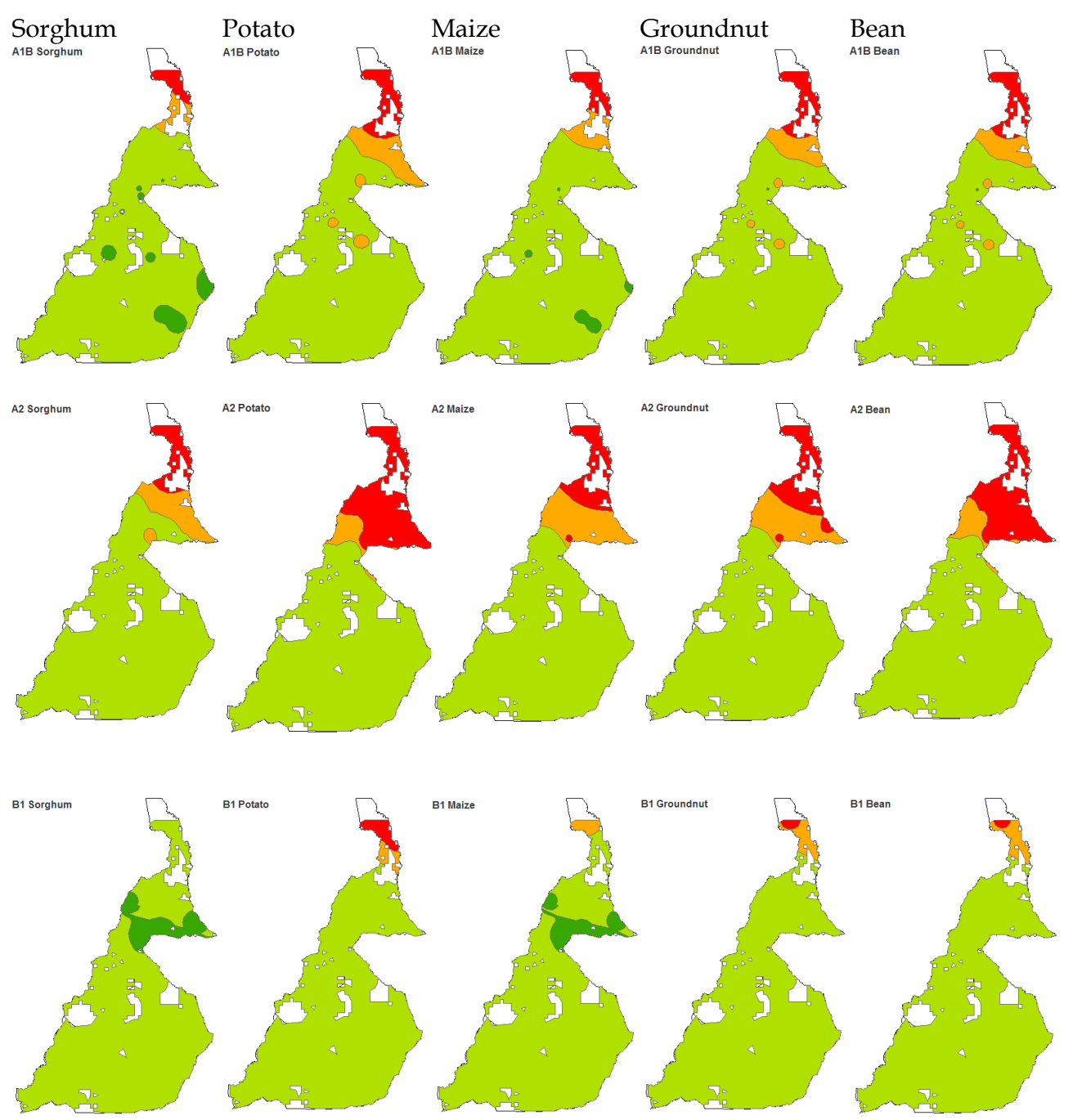

\section{Legend}

\begin{tabular}{l} 
Omm Water Requirement \\
$0.1 \mathrm{~mm}-50 \mathrm{~mm}$ Water Requirement \\
$50.1-100 \mathrm{~mm}$ Water Requirement \\
\hline$>100 \mathrm{~mm}$ Water Requirement \\
\hline Area for Other Land Uses Clipped Out
\end{tabular}


Appendix 3. Data derived from modeling and used for interpolation for all crops and all stations.

\begin{tabular}{|c|c|c|c|c|c|c|c|c|c|}
\hline \multirow[b]{2}{*}{ Location } & \multirow[b]{2}{*}{ Crop } & \multicolumn{4}{|c|}{ Crop Water Requirements (mm) } & \multicolumn{4}{|c|}{ Yield Reduction (\%) } \\
\hline & & Baseline & $A 1 B$ & $A 2$ & $B 1$ & Baseline & $A 1 B$ & $A 2$ & $B 1$ \\
\hline \multirow{5}{*}{$\begin{array}{l}\text { Yagoua } \\
\text { Lat: 10,33 } \\
\text { Long: } 15.23\end{array}$} & Beans & 0,7 & 50,4 & 131,9 & 4,8 & 0,0 & 0,2 & 13,3 & 0,0 \\
\hline & Groundnuts & 17,7 & 30,8 & 104,0 & 5,4 & 0,0 & 0,0 & 4,3 & 0,0 \\
\hline & Maize & 0,3 & 29,8 & 96,6 & 0,0 & 0,0 & 0,0 & 1,4 & 0,0 \\
\hline & Potato & 21,3 & 55,6 & 134,4 & 10,1 & 0,7 & 3,7 & 17,1 & 1,0 \\
\hline & Sorghum & 0,7 & 10,8 & 61,1 & 0,0 & 0,0 & 0,0 & 0,0 & 0,0 \\
\hline \multirow{5}{*}{\begin{tabular}{|l} 
Figuil \\
\\
Lat: 9,75 \\
Long: 13,97
\end{tabular}} & Beans & 0,0 & 9,2 & 44,5 & 1,3 & 0,0 & 0,0 & 0,0 & 0,0 \\
\hline & Groundnuts & 0,0 & 3,5 & 24,2 & 1,9 & 0,0 & 0,0 & 0,0 & 0,0 \\
\hline & Maize & 0,0 & 0,8 & 30,6 & 0,0 & 0,0 & 0,0 & 0,0 & 0,0 \\
\hline & Potato & 2,4 & 7,1 & 43,3 & 3,6 & 0,6 & 1,2 & 1,7 & 0,7 \\
\hline & Sorghum & 0,0 & 0,0 & 5,9 & 0,0 & 0,0 & 0,0 & 0,0 & 0,0 \\
\hline \multirow{5}{*}{$\begin{array}{l}\text { Guider } \\
\text { Lat: } 9,93 \\
\text { Long: } 13,93\end{array}$} & Beans & 0,3 & 0,0 & 4,9 & 1,3 & 0,0 & 0,0 & 0,0 & 0,0 \\
\hline & Groundnuts & 0,0 & 3,5 & 2,5 & 1,9 & 0,0 & 0,0 & 0,0 & 0,0 \\
\hline & Maize & 0,0 & 0,0 & 4,5 & 0,0 & 0,0 & 0,0 & 0,0 & 0,0 \\
\hline & Potato & 2,5 & 4,5 & 3,2 & 2,4 & 0,7 & 1,2 & 0,0 & 0,7 \\
\hline & Sorghum & 0,0 & 0,0 & 4,5 & 0,0 & 0,0 & 0,0 & 0,0 & 0,0 \\
\hline \multirow{5}{*}{$\begin{array}{l}\text { Mora } \\
\text { Lat: } 10,05 \\
\text { Long: } 14,15\end{array}$} & Beans & 0,0 & 64,6 & 152,4 & 6,3 & 0,0 & 2,1 & 20,3 & 0,0 \\
\hline & Groundnuts & 14,2 & 42,5 & 123,2 & 7,1 & 0,0 & 0,1 & 8,0 & 0,0 \\
\hline & Maize & 0,0 & 40,7 & 117,4 & 0,8 & 0,0 & 0,0 & 7,6 & 0,0 \\
\hline & Potato & 19,9 & 72,9 & 156,8 & 14,1 & 0,5 & 6,5 & 23,0 & 1,0 \\
\hline & Sorghum & 0,6 & 22,0 & 82,2 & 0,8 & 0,0 & 0,0 & 0,0 & 0,0 \\
\hline \multirow{5}{*}{$\begin{array}{l}\text { Mokolo } \\
\text { Lat: } 10,78 \\
\text { Long: } 13,73 \\
\end{array}$} & Beans & 0,0 & 28,8 & 97,3 & 1,5 & 0,0 & 0,0 & 3,2 & 0,0 \\
\hline & Groundnuts & 15,0 & 13,2 & 68,8 & 2,4 & 0,0 & 0,0 & 0,1 & 0,0 \\
\hline & Maize & 0,0 & 14,6 & 64,8 & 0,0 & 0,0 & 0,0 & 0,0 & 0,0 \\
\hline & Potato & 20,8 & 27,8 & 101,2 & 7,1 & 0,0 & 1,7 & 8,9 & 0,8 \\
\hline & Sorghum & 0,7 & 1,9 & 34,2 & 0,0 & 0,0 & 0,0 & 0,0 & 0,0 \\
\hline \multirow{5}{*}{$\begin{array}{l}\text { Kaele } \\
\text { Lat: 10,1 } \\
\text { Long: 14,45 } \\
\end{array}$} & Beans & 0,3 & 31,5 & 109,9 & 3,5 & 0,0 & 0,0 & 6,8 & 0,0 \\
\hline & Groundnuts & 9,5 & 14,5 & 82,7 & 4,1 & 0,0 & 0,0 & 1,0 & 0,0 \\
\hline & Maize & 0,0 & 14,0 & 75,3 & 0,0 & 0,0 & 0,0 & 0,0 & 0,0 \\
\hline & Potato & 14,7 & 32,0 & 112,5 & 8,7 & 0,7 & 1,5 & 11,9 & 0,9 \\
\hline & Sorghum & 0,0 & 0,7 & 41,1 & 0,0 & 0,0 & 0,0 & 0,0 & 0,0 \\
\hline \multirow{5}{*}{$\begin{array}{l}\text { Kousseri } \\
\text { Lat: } 12,08 \\
\text { Long: } 15,03 \\
\end{array}$} & Beans & 79,0 & 199,2 & 293,6 & 86,7 & 0,3 & 32,0 & 50,1 & 5,0 \\
\hline & Groundnuts & 129,6 & 172,5 & 261,5 & 81,0 & 4,2 & 14,3 & 24,5 & 2,0 \\
\hline & Maize & 87,2 & 156,2 & 251,6 & 50,5 & 0,0 & 20,2 & 40,3 & 0,0 \\
\hline & Potato & 162,8 & 206,9 & 295,7 & 113,6 & 15,1 & 31,9 & 46,6 & 11,3 \\
\hline & Sorghum & 55,7 & 118,9 & 200,3 & 31,8 & 0,0 & 5,7 & 19,3 & 0,0 \\
\hline
\end{tabular}




\begin{tabular}{|c|c|c|c|c|c|c|c|c|c|}
\hline \multirow{5}{*}{\begin{tabular}{|l} 
Makari \\
Lat: 12,58 \\
Long: 14,47 \\
\end{tabular}} & Beans & 164,3 & 223,9 & 321,9 & 108,1 & 19,2 & 36,7 & 55,1 & 9,5 \\
\hline & Groundnuts & 223,7 & 196,6 & 291,0 & 112,9 & 16,4 & 16,7 & 27,2 & 3,6 \\
\hline & Maize & 183,2 & 179,9 & 278,9 & 72,7 & 16,0 & 25,1 & 45,8 & 0,2 \\
\hline & Potato & 258,9 & 231,8 & 325,9 & 146,5 & 34,5 & 35,4 & 50,4 & 15,3 \\
\hline & Sorghum & 134,9 & 135,5 & 224,2 & 47,2 & 0,0 & 9,1 & 23,4 & 0,0 \\
\hline \multirow{5}{*}{$\begin{array}{l}\text { Waza } \\
\text { Lat: } 11,4 \\
\text { Long: } 14,57 \\
\end{array}$} & Beans & 46,3 & 125,2 & 218,8 & 30,3 & 0,0 & 14,2 & 31,1 & 0,0 \\
\hline & Groundnuts & 62,3 & 99,2 & 185,1 & 17,2 & 0,0 & 5,0 & 13,8 & 0,0 \\
\hline & Maize & 33,1 & 91,8 & 177,4 & 3,6 & 0,0 & 5,5 & 19,7 & 0,0 \\
\hline & Potato & 92,6 & 134,8 & 220,8 & 44,8 & 3,0 & 17,0 & 31,0 & 4,2 \\
\hline & Sorghum & 8,9 & 60,9 & 126,9 & 3,0 & 0,0 & 0,0 & 4,1 & 0,0 \\
\hline \multirow{5}{*}{$\begin{array}{l}\text { Garoua } \\
\text { Lat: } 9,33 \\
\text { Long: } 13,38 \\
\end{array}$} & Beans & 12,2 & 33,6 & 18,1 & 7,4 & 0,0 & 0,0 & 0,0 & 0,0 \\
\hline & Groundnuts & 4,4 & 18,5 & 3,7 & 7,4 & 0,0 & 0,0 & 0,0 & 0,0 \\
\hline & Maize & 7,8 & 15,1 & 5,6 & 5,6 & 0,0 & 0,0 & 0,0 & 0,0 \\
\hline & Potato & 14,2 & 37,6 & 16,8 & 9,3 & 0,1 & 0,3 & 0,1 & 0,1 \\
\hline & Sorghum & 0,0 & 3,6 & 4,5 & 5,6 & 0,0 & 0,0 & 0,0 & 0,0 \\
\hline \multirow{5}{*}{\begin{tabular}{|l} 
Belel \\
Lat: 7,05 \\
Long: 14,43 \\
\end{tabular}} & Beans & 0,0 & 2,0 & 1,6 & 4,7 & 0,0 & 0,0 & 0,0 & 0,0 \\
\hline & Groundnuts & 3,4 & 2,6 & 1,6 & 4,7 & 0,0 & 0,0 & 0,0 & 0,0 \\
\hline & Maize & 0,0 & 0,0 & 3,2 & 3,5 & 0,0 & 0,0 & 0,0 & 0,0 \\
\hline & Potato & 4,3 & 3,4 & 2,0 & 5,8 & 0,0 & 0,0 & 0,0 & 0,0 \\
\hline & Sorghum & 0,0 & 0,0 & 3,2 & 3,5 & 0,0 & 0,0 & 0,0 & 0,0 \\
\hline \multirow{5}{*}{\begin{tabular}{|l} 
Bebeni \\
Lat: 9,17 \\
Long: 13,54 \\
\end{tabular}} & Beans & 12,0 & 58,8 & 44,2 & 20,5 & 0,0 & 0,0 & 0,0 & 0,0 \\
\hline & Groundnuts & 4,3 & 41,5 & 22,9 & 7,9 & 0,0 & 0,0 & 0,0 & 0,0 \\
\hline & Maize & 7,6 & 34,5 & 25,5 & 8,0 & 0,0 & 0,0 & 0,0 & 0,0 \\
\hline & Potato & 14,1 & 61,9 & 47,1 & 18,7 & 0,1 & 0,7 & 0,2 & 0,1 \\
\hline & Sorghum & 0,0 & 9,0 & 5,7 & 5,7 & 0,0 & 0,0 & 0,0 & 0,0 \\
\hline \multirow{5}{*}{$\begin{array}{l}\text { Djohong } \\
\text { Lat: } 6,83 \\
\text { Long: } 14,7 \\
\end{array}$} & Beans & 0,0 & 2,1 & 1,6 & 4,5 & 0,0 & 0,0 & 0,0 & 0,0 \\
\hline & Groundnuts & 3,3 & 2,7 & 1,6 & 4,5 & 0,0 & 0,0 & 0,0 & 0,0 \\
\hline & Maize & 0,0 & 0,0 & 3,2 & 3,4 & 0,0 & 0,0 & 0,0 & 0,0 \\
\hline & Potato & 4,2 & 3,4 & 2,0 & 5,7 & 0,0 & 0,0 & 0,0 & 0,0 \\
\hline & Sorghum & 0,0 & 0,0 & 3,1 & 3,4 & 0,0 & 0,0 & 0,0 & 0,0 \\
\hline \multirow{5}{*}{$\begin{array}{l}\text { Magba } \\
\text { Lat: } 6 \\
\text { Long: } 11,22 \\
\end{array}$} & Beans & 2,0 & 6,8 & 5,2 & 3,4 & 0,0 & 0,0 & 0,0 & 0,0 \\
\hline & Groundnuts & 1,5 & 6,8 & 5,2 & 3,4 & 0,0 & 0,0 & 0,0 & 0,0 \\
\hline & Maize & 0,0 & 5,1 & 3,9 & 3,5 & 0,0 & 0,0 & 0,0 & 0,0 \\
\hline & Potato & 1,9 & 8,5 & 6,5 & 4,2 & 0,0 & 0,0 & 0,0 & 0,0 \\
\hline & Sorghum & 0,0 & 5,1 & 3,9 & 3,5 & 0,0 & 0,0 & 0,0 & 0,0 \\
\hline \multirow{4}{*}{$\begin{array}{l}\text { Touboro } \\
\text { Lat: } 7,78 \\
\text { Long: } 15,6 \\
\end{array}$} & Beans & 0,0 & 5,8 & 2,1 & 6,0 & 0,0 & 0,0 & 0,0 & 0,0 \\
\hline & Groundnuts & 4,0 & 5,7 & 2,1 & 6,0 & 0,0 & 0,0 & 0,0 & 0,0 \\
\hline & Maize & 0,0 & 0,0 & 4,0 & 4,5 & 0,0 & 0,0 & 0,0 & 0,0 \\
\hline & Potato & 4,9 & 9,7 & 2,6 & 7,5 & 0,0 & 0,0 & 0,0 & 0,0 \\
\hline
\end{tabular}




\begin{tabular}{|c|c|c|c|c|c|c|c|c|c|}
\hline & Sorghum & 0,0 & 0,0 & 3,9 & 4,5 & 0,0 & 0,0 & 0,0 & 0,0 \\
\hline \multirow{5}{*}{$\begin{array}{l}\text { Tchollire } \\
\text { Lat: } 8,4 \\
\text { Long: } 14,17 \\
\end{array}$} & Beans & 27,3 & 27,1 & 15,7 & 8,9 & 0,0 & 0,0 & 0,0 & 0,0 \\
\hline & Groundnuts & 12,3 & 12,6 & 3,2 & 7,6 & 0,0 & 0,0 & 0,0 & 0,0 \\
\hline & Maize & 18,7 & 11,4 & 7,0 & 5,7 & 0,0 & 0,0 & 0,0 & 0,0 \\
\hline & Potato & 26,8 & 25,0 & 8,1 & 9,5 & 0,1 & 0,2 & 0,1 & 0,0 \\
\hline & Sorghum & 2,1 & 0,0 & 4,8 & 5,7 & 0,0 & 0,0 & 0,0 & 0,0 \\
\hline \multirow{5}{*}{$\begin{array}{l}\text { Rey Bouba } \\
\text { Lat: } 8,67 \\
\text { Long: } 14,18 \\
\end{array}$} & Beans & 27,1 & 57,6 & 40,7 & 15,7 & 0,0 & 0,0 & 0,0 & 0,0 \\
\hline & Groundnuts & 12,4 & 38,6 & 17,9 & 8,3 & 0,0 & 0,0 & 0,0 & 0,0 \\
\hline & Maize & 18,5 & 30,4 & 20,0 & 5,8 & 0,0 & 0,0 & 0,0 & 0,0 \\
\hline & Potato & 26,6 & 62,7 & 44,6 & 16,5 & 0,1 & 0,8 & 0,3 & 0,1 \\
\hline & Sorghum & 2,0 & 7,8 & 5,3 & 5,8 & 0,0 & 0,0 & 0,0 & 0,0 \\
\hline \multirow{5}{*}{\begin{tabular}{|l} 
Poli \\
Lat: 8,48 \\
Long: 13,25 \\
\end{tabular}} & Beans & 0,0 & 11,9 & 4,3 & 7,0 & 0,0 & 0,0 & 0,0 & 0,0 \\
\hline & Groundnuts & 4,1 & 5,5 & 2,4 & 7,0 & 0,0 & 0,0 & 0,0 & 0,0 \\
\hline & Maize & 0,0 & 0,0 & 4,2 & 5,3 & 0,0 & 0,0 & 0,0 & 0,0 \\
\hline & Potato & 5,1 & 11,3 & 3,0 & 8,8 & 0,1 & 0,1 & 0,0 & 0,0 \\
\hline & Sorghum & 0,0 & 0,0 & 4,3 & 5,3 & 0,0 & 0,0 & 0,0 & 0,0 \\
\hline \multirow{5}{*}{$\begin{array}{l}\text { Pitoa } \\
\text { Lat: 9,38 } \\
\text { Long: 13,53 } \\
\end{array}$} & Beans & 12,7 & 29,2 & 17,9 & 7,6 & 0,0 & 0,0 & 0,0 & 0,0 \\
\hline & Groundnuts & 4,7 & 13,8 & 2,5 & 7,4 & 0,0 & 0,0 & 0,0 & 0,0 \\
\hline & Maize & 8,2 & 12,3 & 6,4 & 5,6 & 0,0 & 0,0 & 0,0 & 0,0 \\
\hline & Potato & 14,6 & 28,4 & 11,6 & 9,3 & 0,1 & 0,0 & 0,1 & 0,1 \\
\hline & Sorghum & 0,0 & 0,0 & 4,5 & 5,6 & 0,0 & 0,0 & 0,0 & 0,0 \\
\hline \multirow{5}{*}{\begin{tabular}{|l} 
Banyo \\
Lat: 6,78 \\
Long: 11,81 \\
\end{tabular}} & Beans & 2,1 & 6,3 & 4,6 & 3,1 & 0,0 & 0,0 & 0,0 & 0,0 \\
\hline & Groundnuts & 1,6 & 6,3 & 4,6 & 3,1 & 0,0 & 0,0 & 0,0 & 0,0 \\
\hline & Maize & 0,0 & 4,7 & 3,5 & 3,3 & 0,0 & 0,0 & 0,0 & 0,0 \\
\hline & Potato & 2,0 & 7,9 & 5,8 & 3,9 & 0,0 & 0,0 & 0,0 & 0,0 \\
\hline & Sorghum & 0,0 & 4,7 & 3,5 & 3,3 & 0,0 & 0,0 & 0,0 & 0,0 \\
\hline \multirow{5}{*}{$\begin{array}{l}\text { Tibati } \\
\text { Lat: } 6,48 \\
\text { Long: } 12,63 \\
\end{array}$} & Beans & 2,1 & 6,4 & 4,8 & 3,2 & 0,0 & 0,0 & 0,0 & 0,0 \\
\hline & Groundnuts & 1,5 & 6,4 & 4,8 & 3,2 & 0,0 & 0,0 & 0,0 & 0,0 \\
\hline & Maize & 0,0 & 4,8 & 3,6 & 3,4 & 0,0 & 0,0 & 0,0 & 0,0 \\
\hline & Potato & 3,5 & 8,0 & 6,0 & 3,9 & 0,0 & 0,0 & 0,0 & 0,0 \\
\hline & Sorghum & 0,0 & 4,8 & 3,6 & 3,3 & 0,0 & 0,0 & 0,0 & 0,0 \\
\hline \multirow{5}{*}{$\begin{array}{l}\text { Ngoundal } \\
\text { Lat: } 6,5 \\
\text { Long: } 13,27 \\
\end{array}$} & Beans & 2,4 & 7,2 & 5,8 & 3,6 & 0,0 & 0,0 & 0,0 & 0,0 \\
\hline & Groundnuts & 2,0 & 7,2 & 5,8 & 3,6 & 0,0 & 0,0 & 0,0 & 0,0 \\
\hline & Maize & 0,0 & 5,4 & 4,3 & 3,7 & 0,0 & 0,0 & 0,0 & 0,0 \\
\hline & Potato & 5,4 & 9,0 & 7,2 & 4,5 & 0,0 & 0,0 & 0,0 & 0,0 \\
\hline & \begin{tabular}{|l|} 
Sorghum \\
\end{tabular} & 0,0 & 5,4 & 4,3 & 3,6 & 0,0 & 0,0 & 0,0 & 0,0 \\
\hline \multirow{3}{*}{$\begin{array}{l}\text { Ngoundere } \\
\text { Lat: } 7,35 \\
\text { Long: } 13,56 \\
\end{array}$} & Beans & 4,6 & 7,4 & 6,4 & 3,7 & 0,0 & 0,0 & 0,0 & 0,0 \\
\hline & Groundnuts & 4,2 & 7,4 & 6,4 & 3,7 & 0,0 & 0,0 & 0,0 & 0,0 \\
\hline & Maize & 0,0 & 5,6 & 4,4 & 3,7 & 0,0 & 0,0 & 0,0 & 0,0 \\
\hline
\end{tabular}




\begin{tabular}{|l|l|c|c|c|c|c|c|c|c|}
\hline & Potato & 7,6 & 9,3 & 13,0 & 4,6 & 0,0 & 0,0 & 0,0 & 0,0 \\
\cline { 2 - 10 } & Sorghum & 0,0 & 5,6 & 4,4 & 3,7 & 0,0 & 0,0 & 0,0 & 0,0 \\
\hline \multirow{4}{*}{$\begin{array}{l}\text { Meiganga } \\
\text { Lat: 6,53 } \\
\text { Long: } 14,36\end{array}$} & Beans & 2,7 & 7,2 & 5,7 & 3,5 & 0,0 & 0,0 & 0,0 & 0,0 \\
\cline { 2 - 10 } & Groundnuts & 2,3 & 7,2 & 5,7 & 3,5 & 0,0 & 0,0 & 0,0 & 0,0 \\
\cline { 2 - 10 } & Maize & 0,0 & 5,4 & 4,3 & 3,6 & 0,0 & 0,0 & 0,0 & 0,0 \\
\cline { 2 - 10 } & Potato & 5,7 & 9,0 & 7,1 & 4,4 & 0,0 & 0,0 & 0,0 & 0,0 \\
\hline \multirow{4}{*}{$\begin{array}{l}\text { Tignere } \\
\text { Lat: 7,73 } \\
\text { Long: } 12,65\end{array}$} & Sorghum & 0,0 & 5,4 & 4,3 & 3,6 & 0,0 & 0,0 & 0,0 & 0,0 \\
\cline { 2 - 10 } & Geans & 2,5 & 7,6 & 6,0 & 3,8 & 0,0 & 0,0 & 0,0 & 0,0 \\
\cline { 2 - 10 } & Groundnuts & 2,0 & 7,6 & 6,0 & 3,8 & 0,0 & 0,0 & 0,0 & 0,0 \\
\cline { 2 - 10 } & Potato & 0,0 & 5,7 & 4,5 & 3,8 & 0,0 & 0,0 & 0,0 & 0,0 \\
\hline
\end{tabular}

\section{References}

Allen, R., L. Pereira, D. Raes, and M. Smith. 1998. Crop evapotranspiration-Guidelines for computing crop water requirements-FAO Irrigation and drainage paper 56. FAO, Rome 300.

Baulcombe, D., I. Crute, B. Davies, J. Dunwell, M. Gale, J. Jones, J. Pretty, W. Sutherland, and C. Toulmin. 2009. Reaping the benefits: science and the sustainable intensification of global agriculture. London, UK: The Royal Society.

Binswanger, H. and P. Pingali. 1988. Technological priorities for farming in sub-Saharan Africa. The World Bank Research Observer 3:81.

Boko, M. N., A. Nyong, C. Vogel, A. Githeko, M. Medany, B. Osman-Elasha, R. Tabo and P. Yanda. 2007. Africa. Climate Change 2007: Impacts, Adaptation and Vulnerability. Contribution of Working Group II to the Fourth Assessment Report of the Intergovernmental Panel on Climate Change. Cambridge Univ Pr.

Boserup, E. and N. Kaldor. 2005. The conditions of agricultural growth: the economics of agrarian change under population pressure. Aldine De Gruyter.

Bruinsma, J. 2003. World agriculture: towards 2015/2030: an FAO perspective. Earthscan/James \& James.

Channell, R. and M. Lomolino. 2000. Dynamic biogeography and conservation of endangered species. Nature 403:84-86.

Clarke, D., M. Smith, and K. El-Askari. 1998. CropWat for Windows: user guide. Food and Agriculture Organization:1-45.

Cooper, P., K. Rao, P. Singh, J. Dimes, P. Traore, K. Rao, P. Dixit, and S. Twomlow. 2009. Farming with current and future climate risk: advancing a 'Hypothesis of Hope'for rainfed agriculture in the semi-arid tropics.

CRED. 2011. The International Disaster Database. Centre for Research on the Epidemiology of Disasters, Université Catholique de Louvain. Brussels, Belgium.

Davies, B. and M. Chaves. 2010. Drought effects and water use efficiency: improving crop production in dry environments. Functional Plant Biology 37.

De Janvry, A. 2009. AERC Conference on Agriculture for Development in Sub-Saharan Africa: Introduction. 
Demont, M., P. Jouve, J. Stessens, and E. Tollens. 2007. Boserup versus Malthus revisited: Evolution of farming systems in Northern Côte d'Ivoire. Agricultural Systems 93:215-228.

Döll, P. 2002. Impact of climate change and variability on irrigation requirements: a global perspective. Climatic Change 54:269-293.

Easterling, W., P. Aggarwal, P. Batima, K. Brander, L. Erda, S. Howden, A. Kirilenko, J. Morton, J. Soussana, and J. Schmidhuber. 2007. Food, fibre and forest products. Climate change 2007: impacts, adaptation and vulnerability. Contribution of Working Group II to the Fourth Assessment Report of the Intergovernmental Panel on Climate Change, Parry, pp273-313, ML et al (eds).

Eid, H. and N. El-Mowelhi. 1998. Impact of climate change on field crops and water needs in Egypt.

El-Shaer, H., C. Rosenzweig, A. Iglesias, M. Eid, and D. Hillel. 1997. Impact of climate change on possible scenarios for Egyptian agriculture in the future. Mitigation and Adaptation Strategies for Global Change 1:233-250.

Falkenmark, M. and J. Rockström. 2008. Building resilience to drought in desertificationprone savannas in Sub-Saharan Africa: The water perspective. Pages 93-102. John Wiley \& Sons.

Fan, S., T. Mogues, and S. Benin. 2009. Setting priorities for public spending for agricultural and rural development in Africa. Policy briefs.

FAOSTAT, F. 2010. Statistical Databases. Food and Agriculture Organization of the United Nations, Washington, DC:128-130.

Grieser, J., R. Gommes, and M. Bernardi. 2006. New LocClim-the local climate estimator of FAO.

Iglesias, A., L. Garrote, F. Flores, and M. Moneo. 2007. Challenges to manage the risk of water scarcity and climate change in the Mediterranean. Water Resources Management 21:775-788.

IPCC. 2007. Climate Change 2007: Synthesis Report. IPCC Secretariat, 7 bis Avenue de la Paix C. P. 2300 Geneva 2 CH- 1211 Switzerland.

Jayne, T., D. Mather, and E. Mghenyi. 2010. Principal Challenges Confronting Smallholder Agriculture in Sub-Saharan Africa. World Development.

Khalil, F., H. Farag, G. El Afandi, and S. Ouda. 2009. Vulnerability and adaptation of wheat to climate change in Middle Egypt. Pages 12-15.

Lankford, B. 2009. Viewpoint-The right irrigation? Policy directions for agricultural water management in Sub-Saharan Africa. Water Alternatives 2:476-480.

Laux, P., G. Jäckel, R. Tingem, and H. Kunstmann. 2010. Impact of climate change on agricultural productivity under rainfed conditions in Cameroon--A method to improve attainable crop yields by planting date adaptations. Agricultural and Forest Meteorology.

Li, Y., W. Ye, M. Wang, and X. Yan. 2009. Climate change and drought: a risk assessment of crop-yield impacts. Clim. Res 39:31-46.

Lobell, D. and C. Field. 2007. Global scale climate-crop yield relationships and the impacts of recent warming. Environmental Research Letters 2:014002.

Longley, P. 2005. Geographic information systems and science. John Wiley \& Sons Inc.

Maiti, R. K. 1996. Sorghum science. Science Publishers, Lebanon, NH.

McSweeney, C., G. Lizcano, M. New, and X. Lu. 2010. The UNDP Climate Change Country Profiles: Cameroon. Bulletin of the American Meteorological Society 91:157-166.

Mokwunye, A., A. de Jager, and E. Smaling. 1996. Restoring and maintaining the productivity of West African soils: key to sustainable development. International Fertilizer Development Center. 
Molua, E. and C. Lambi. 2006. Assessing the impact of climate on crop water use and crop water productivity: The CROPWAT analysis of three districts in Cameroon. CEEPA Discussion paper.

Morton, J. 2007. The impact of climate change on smallholder and subsistence agriculture. Proceedings of the National Academy of Sciences 104:19680.

Moyin-Jesu, E. 2007. Use of plant residues for improving soil fertility, pod nutrients, root growth and pod weight of okra (Abelmoschus esculentum L). Bioresource technology 98:2057-2064.

Nelson, G. 2009. Climate Change: Impact on agriculture and costs of adaptation. Intl Food Policy Res Inst.

Parry, M., C. Rosenzweig, A. Iglesias, M. Livermore, and G. Fischer. 2004. Effects of climate change on global food production under SRES emissions and socio-economic scenarios. Global Environmental Change 14:53-67.

Peng, X., Y. Zhang, J. Cai, Z. Jiang, and S. Zhang. 2009. Photosynthesis, growth and yield of soybean and maize in a tree-based agroforestry intercropping system on the Loess Plateau. Agroforestry systems 76:569-577.

Prasad, P., S. Pisipati, R. Mutava, and M. Tuinstra. 2008. Sensitivity of grain sorghum to high temperature stress during reproductive development. Crop Sci 48:1911-1917.

Ringler, C., E. Bryan, A. Biswas, and S. Cline. 2010. Water and Food Security Under Global Change. Global Change: Impacts on Water and food Security:3-15.

Sánchez, P. 2010. Tripling crop yields in tropical Africa. Nature Geoscience 3:299-300.

Sanchez, P., G. Denning, and G. Nziguheba. 2009. The African green revolution moves forward. Food Security 1:37-44.

Stancalie, G., A. Marica, and L. Toulios. 2010. Using earth observation data and CROPWAT model to estimate the actual crop evapotranspiration. Physics and Chemistry of the Earth, Parts A/B/C 35:25-30.

Tenywa, M. and M. Bekunda. 2009. Managing soils in Sub-Saharan Africa: Challenges and opportunities for soil and water conservation. Journal of Soil and Water Conservation 64:44A.

Traore, S., Y. Wang, T. Kerh, and A. Ouedraogo. 2007. Application of CROPWAT simulation model for rainfed and irrigated agriculture water planning in Burkina Faso. Journal of International Cooperation 3:1-26.

Vanacker, V., M. Linderman, F. Lupo, S. Flasse, and E. Lambin. 2005. Impact of short term rainfall fluctuation on interannual land cover change in sub Saharan Africa. Global Ecology and Biogeography 14:123-135.

Wani, S., J. Rockström, and T. Oweis. 2009. Rainfed Agriculture: unlocking the potential. CABI Publishing.

Williams, N. 2009. Feeding the future world. Current Biology 19:R968-R969.

Wojtkowski, P. 2008. Ensuring Food Security. science 320:611.

Yengoh, G., A. Ato, and M. Svensson. 2009. Technology Adoption in Small-Scale Agriculture: The Case of Cameroon and Ghana. Science, Technology \& Innovation Studies 5.

Yengoh, G., A. Tchuinte, F. Armah, and J. Odoi. 2010. Impact of prolonged rainy seasons on food crop production in Cameroon. Mitigation and Adaptation Strategies for Global Change:1-17.

Yengoh, G. T., T. Hickler, and A. Tchuinte. 2011. Agro-climatic Resources and Challenges to Food Production in Cameroon. Geocarto International:1-1. 


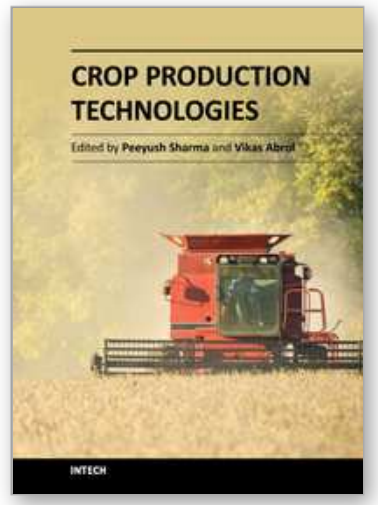

\author{
Crop Production Technologies \\ Edited by Dr. Peeyush Sharma
}

ISBN 978-953-307-787-1

Hard cover, 276 pages

Publisher InTech

Published online 05, January, 2012

Published in print edition January, 2012

Crop production depends on the successful implementation of the soil, water, and nutrient management technologies. Food production by the year 2020 needs to be increased by 50 percent more than the present levels to satisfy the needs of around 8 billion people. Much of the increase would have to come from intensification of agricultural production. Importance of wise usage of water, nutrient management, and tillage in the agricultural sector for sustaining agricultural growth and slowing down environmental degradation calls for urgent attention of researchers, planners, and policy makers. Crop models enable researchers to promptly speculate on the long-term consequences of changes in agricultural practices. In addition, cropping systems, under different conditions, are making it possible to identify the adaptations required to respond to changes. This book adopts an interdisciplinary approach and contributes to this new vision. Leading authors analyze topics related to crop production technologies. The efforts have been made to keep the language as simple as possible, keeping in mind the readers of different language origins. The emphasis has been on general descriptions and principles of each topic, technical details, original research work, and modeling aspects. However, the comprehensive journal references in each area should enable the reader to pursue further studies of special interest. The subject has been presented through fifteen chapters to clearly specify different topics for convenience of the readers.

\title{
How to reference
}

In order to correctly reference this scholarly work, feel free to copy and paste the following:

Genesis T. Yengoh, Sara Brogaard and Lennart Olsson (2012). Crop Water Requirements in Cameroon's Savanna Zones Under Climate Change Scenarios and Adaptation Needs, Crop Production Technologies, Dr. Peeyush Sharma (Ed.), ISBN: 978-953-307-787-1, InTech, Available from:

http://www.intechopen.com/books/crop-production-technologies/crop-water-requirements-in-cameroon-ssavanna-zones-under-climate-change-scenarios-and-adaptation-ne

\section{INTECH}

open science | open minds

\section{InTech Europe}

University Campus STeP Ri

Slavka Krautzeka 83/A

51000 Rijeka, Croatia

Phone: +385 (51) 770447

\section{InTech China}

Unit 405, Office Block, Hotel Equatorial Shanghai

No.65, Yan An Road (West), Shanghai, 200040, China

中国上海市延安西路65号上海国际贵都大饭店办公楼 405 单元

Phone: +86-21-62489820 
Fax: +385 (51) 686166

Fax: +86-21-62489821

www.intechopen.com 
(C) 2012 The Author(s). Licensee IntechOpen. This is an open access article distributed under the terms of the Creative Commons Attribution 3.0 License, which permits unrestricted use, distribution, and reproduction in any medium, provided the original work is properly cited. 